\title{
Analysis of the Liver of Fish Species Prochilodus lineatus Altered Environments, Analyzed with ImageJ
}

\author{
Vanessa Ellen Wendt Campos ${ }^{1}$, Bruno Fiorelini Pereira ${ }^{2 *}$, Dimítrius Leonardo Pitol ${ }^{3}$, \\ Rebeca Mamede da Silva Alves' ${ }^{1}$, Flavio Henrique Caetano ${ }^{1}$
}

\author{
${ }^{1}$ Department of Biology, Institute of Biosciences Rio Claro, São Paulo State University, São Paulo, Brazil \\ ${ }^{2}$ Universidade Federal do Oeste da Bahia, Barreiras-BA, Brazil \\ ${ }^{3}$ Department of Morphology, Physiology and Basic Pathology, School of Dentistry of Ribeirão Preto, University of São Paulo, São Paulo, \\ Brazil
}

Email: `brunofp22@hotmail.com,dimitrius@forp.usp.br

How to cite this paper: Campos, V.E.W., Pereira, B.F., Pitol, D.L., da Silva Alves, R.M. and Caetano, F.H. (2017) Analysis of the Liver of Fish Species Prochilodus lineatus Altered Environments, Analyzed with ImageJ. Microscopy Research, 5, 1-9. http://dx.doi.org/10.4236/mr.2017.51001

Received: August 30, 2016

Accepted: January 19, 2017

Published: January 22, 2017

Copyright $\odot 2017$ by authors and Scientific Research Publishing Inc. This work is licensed under the Creative Commons Attribution International License (CC BY 4.0).

http://creativecommons.org/licenses/by/4.0/

\section{Open Access}

\begin{abstract}
The fish Prochilodus lineatus (Characiformes, Prochilodontidae), in addition to being a good bioindicator, is also of economic and ecological importance with a broad distribution in the neotropics. Ecotoxicology examines the interaction between environmental chemistry and biota; and in this study we assess alterations of bile and glycogen levels in the fish liver, organ responsible for detoxification, biotransformation and storing nutrients, such as glycogen, and for secreting bile. Fish were separated in three groups to examine the damage caused by the exposure to waters from Lago Azul-Rio Claro-SP and containing diluted biodegradable detergents in comparison to a control group (chlorinated water from an artesian well of UNESP-Campus Rio Claro). A histological analysis was performed on HE and PAS stained sections. The identification of structural changes and the assessment of the area occupied by bile and glycogen were carried out with the software ImageJ, showing that the liver was affected morphologically (cell vacuolization, peripherals nuclei, for example) and problems in bile release and production and storage of glycogen.
\end{abstract}

\section{Keywords}

Liver, Glycogen, Bile, Prochilodus lineatus

\section{Introduction}

The genus Prochilodusis widely distributed in the neotropics, is characterized by average-to-large body size, detritivory, rheophily and migration capacity during the piracema spawning season. Thirteen species have been currently described and are locally 
known in Brazil as curimbatá, curimba, curimatã-pacu (Silva [1]). The species Prochilodus lineatus is widely distributed throughout the basin of Paraná-Paraguai Rivers and Paraíba do Sul River (southeast coast of Brazil). It has a high aquaculture potential due to its low production cost, and is an economically attractive alternative. In the Paraná River Basin, schools of 60 to 80,000 individuals have been reported (Barbieri, et al. [2]), indicating the potential of this species for the fishing industry. Because of these characteristics, its well described biology and sensitivity to pollutants, this species is suitable for toxicity tests (Maduenho, et al. [3]).

According to Mumford, et al. [4], the fish liver is a relatively large organ. Its color ranges from red-brown in carnivore species to light brown in herbivore species, and it can also vary from yellow to white in some seasons of the year, depending on the fish's diet.

The liver is a highly irrigated organ, due to its role in processing and storing nutrients absorbed from the digestive tract, neutralizing and eliminating toxic compounds by biotransformation and bile secretion. This organ consists basically of hepatocytes, which are polyhedral cells with six or more surfaces (Gerber, et al. [5]); and Kupfer cells. Because it is the main organ responsible for the detoxification of xenobiotics, the liver may undergo changes, as it normally accumulates higher concentrations of toxic substances (Maduenho, et al. [3]).

Identified stages of liver degeneration in $P$. lineatus are exposed to DFB (diflubenzuron). According to these authors, Stage I is characterized by clusters of melano macrophages (with cellular and nuclear hypertrophy) and nuclei of hepatocytes displaced toward the periphery. In Stage II, cytoplasmic degeneration observed is associated with nuclear vacuolization, bile stagnation and pyknotic nuclei (Maduenho, et al. [3]). According to Simonato, et al. [6], fish exposed to pollutants, such as petroleum, can exhibit modifications in the liver, such as hypertrophy and lateral displacement of the nucleus, vacuolization and cytoplasmic degeneration, among others. Jiraungkoorskul, et al. [7] conducted toxicological studies with herbicides and observed vacuolization and nuclear pyknosis in the liver and dilation of the Bowman's space in the kidneys of the fish Oreochromis niloticus. In a similar study, (Aguiar, et al. [8]) reported that fenitrothion, another type of herbicide, caused a decrease in glycogen levels in the liver and muscles of the fish Anguilla anguilla. Most morphological lesions, such as hyperplasia, induced by water contaminants are non specific. However, cells are extremely susceptible to them (Maduenho, et al. [3]).

According to Bols, et al. [9] [10], fish are especially important in ecotoxicological studies. With approximately 20,000 different species occupying all aquatic niches, fish are the most diversified group of vertebrates. Thus, the understanding of the effects of pollutants on fish can provide a framework for the assessment of the degradation level of aquatic habitats and also help predict possible impacts for human health. Toxic agents are usually discharged in aquatic habitats in several ways, which humans can be exposed to. Since several biological systems have been preserved throughout evolution, the effects on fish may signal future impacts on human health. Therefore, fish can be used as models for ecotoxicological studies, given their economic importance. For the fishing industry, not only the health of certain target species is of extreme importance, but also of the remaining species is considered critical for the maintenance of fishing 
stocks. The species examined in the present study, $P$. lineatus, is extremely important, although not for the fishing industry, but rather in recreational fishing, which promotes mental health (Campos, et al. [11]).

Based on the information about the damage caused by the absorption of toxic compounds by fish in disturbed habitats, it is possible to better understand the relationship among different ecological levels and how they affect the human population that uses this species in recreational fishing and for consumption. Therefore, we examined possible alterations in the liver tissue, focusing on quantifying bile and glycogen levels in the fish $P$. lineatus.

Thus, the present study provides important information for the population living near Lago Azul, as it involves a disturbed urban area and the effects of common pollutants, such as biodegradable detergents, on the environment. It also quantifies bile and glycogen levels for the first time in ecotoxicological studies of fish. This will allow a deeper understanding of the effects of pollutants on fish and shed light on possible bioindicators to be analyzed and quantified.

\section{Material and Methods}

It was collected 36 specimens of Prochilodus lineatus at ICMBio/CEPTA-Pirassununga, São Paulo, Brazil. Fish were divided into three groups of 12 animals and maintained in three 500-1 polyethylene boxes at $25^{\circ} \mathrm{C}$, exposed to three different conditions, control (G1), detergent (1 ppm), (G2), and Lago Azul (G3). These treatments were chosen due to the growing concern of the possible effects caused by biodegradable detergents and also the water from Lago Azul ( $\left.2^{\circ} 24^{\prime} 39^{\prime \prime} S, 47^{\circ} 33^{\prime} 39^{\prime \prime E}\right)$ Rio Claro-SP, which according to studies carried out by SABESP (water and waste management company owned by São Paulo state), is polluted.

Histological analysis was conducted with a Leica DM2000 microscope fitted with a DFC 280 Leica camera. Images were captured with the software Leica IM50 and analyzed with the software ImageJ 1.44e (Figure 1 and Figure 2).

Fish were sampled twice after 7 and 20 days of experiment. Six fish of each group were anesthetized with $0.01 \%$ benzocaine, a total of 18 fish was sacrificed in each sampling. The liver was removed, fixed with Bouin and processed for historesin and PAS and $\mathrm{H}-\mathrm{E}$ staining, following [12]. The material was examined under light microscope with a 40x objective lens and a Leica DM 2000 camera attached. Analysis was carried out with the software Image $1.44 \mathrm{e}$. Averages obtained from 5-6- $\mu \mathrm{m}$ sections were calculated for each individual. From each section, 5 regions were chosen depending on the type of analysis. For quantitative analysis of bile, regions near bile ducts were chosen, as bile is stored to be later discharged into the duct. To quantify glycogen, five regions distant from large vessels were chosen in order to analyze the largest number of hepatocytes as possible. Statistical analysis was carried out with the software BioStat 5.0 and normality was assessed with the Shapiro-Wilk test, and compared with the KruskalWallis/Dunn test [12].

\section{Results}

The results obtained in the analysis of the total area occupied by bile are presented in 


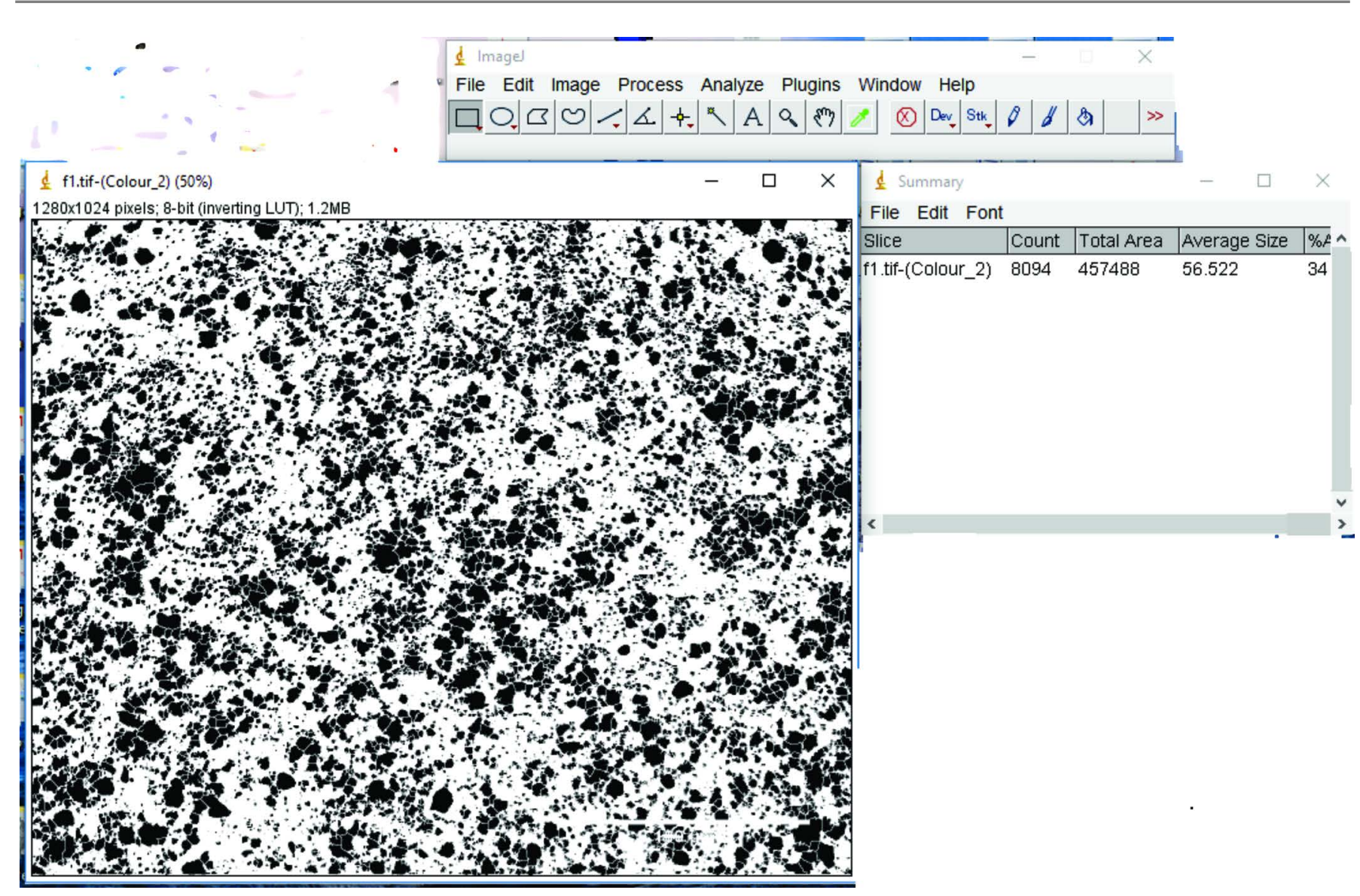

Figure 1. Quantification of glycogen has been processed by ImageJ software (Free software, http://rsb.info.nih.gov/ij).

Table 1. At Day 7, a significant difference was observed between G1 and G2 when compared to G3 ( $\mathrm{p}<0.05)$. At Day 20, a significant difference $(\mathrm{p}<0.05)$ was observed only when G1 and G3 were compared. No differences were observed when G2 was compared to the other two groups.

Fish of G3 at Days 7 and 20 had less glycogen stored when compared to individuals of other groups (Table 1). At Days 7 and 20, glycogen levels in G1 and G3 were significantly different $(\mathrm{p}<0.05)$, as well as in G2 and G3 at Day 7.

Vacuoles were observed in G2 (Figure 3(c) and Figure 3(d)) at Days 7 and 20. In the latter, in addition to vacuoles, bile levels were lower when compared to that of G1 (Figure 3(a) and Figure 3(b)). In G3 (Figure 3(e)) at Days 7 and 20, liver damage was similar to the observed in G2 at Day 20, but the decrease in bile levels was more prominent. At Day 20, G3 exhibit a significant increase in vacuolization and decrease in bile levels.

Regarding the quantification of glycogen granules, the analysis could not be carried out, as the control group exhibited several small granules of glycogen that could not be differentiated by the software, making the analysis unfeasible. The results obtained demonstrated that the exposure to pollutants can produce serious damage to the liver tissue and other organs, as the capacity to store glycogen, the main energy source for the organism, decreases (Figure 4).

In G2 at Day 20 (Figure 4(d)) glycogen area significantly decreased $(\mathrm{p}<0.05)$ when 


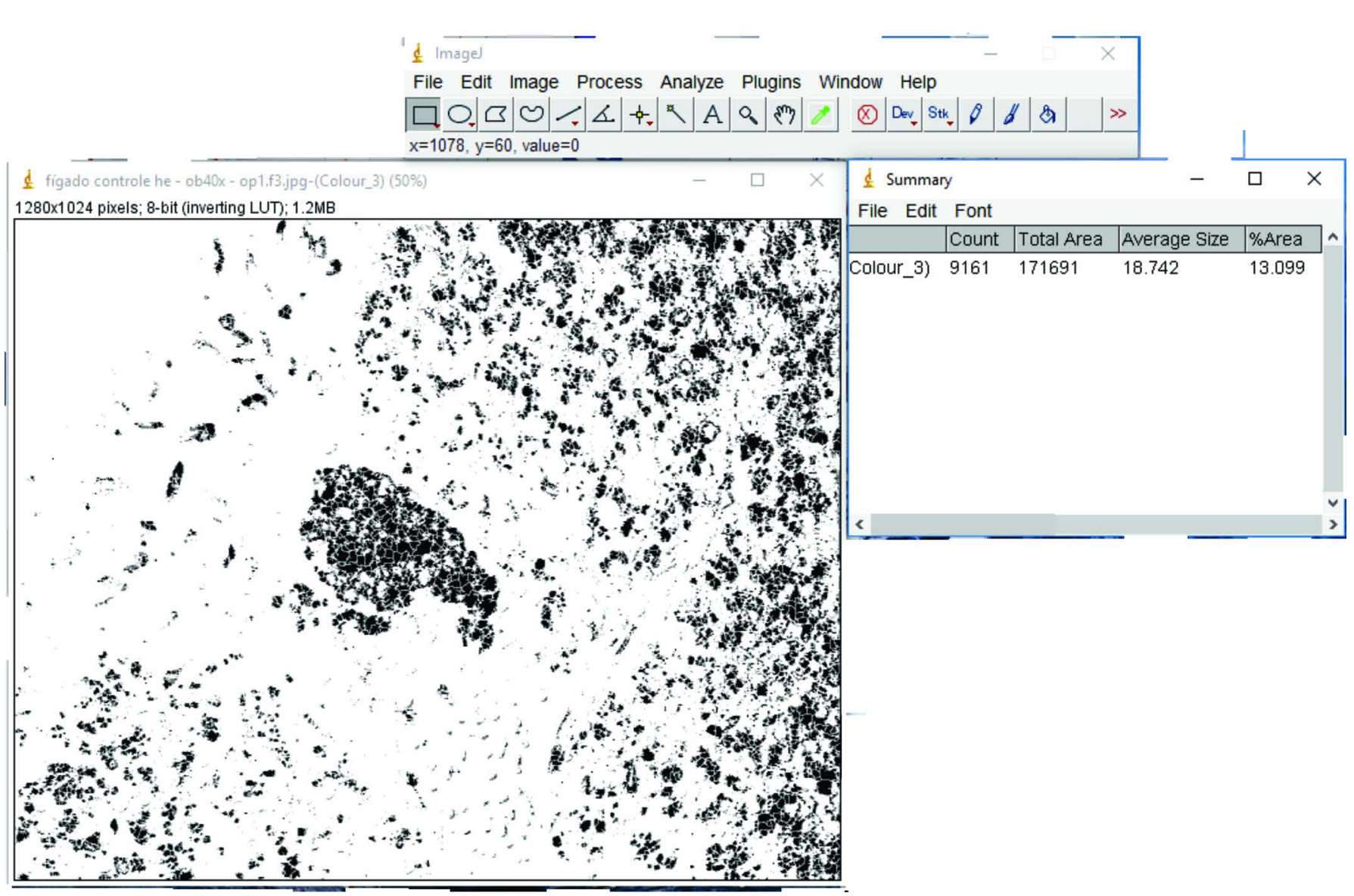

Figure 2. Quantification of bile had been been processed by ImageJ Software (Free software, http://rsb.info.nih.gov/ij).

Table 1. The table shows the average of bile and glycogen in $\mu \mathrm{m}^{2,}$ calculated under magnification of $400 \times$, for each group in 7 and 20 days and the statistic results (p) when compared with the control group. Note the decrease o bile area in G3 group and the decrease of glycogen area in G2 after 20 days and in G3 during all the experiment.

\begin{tabular}{|c|c|c|c|c|c|c|c|c|c|c|}
\hline & \multicolumn{2}{|c|}{ G1 } & \multicolumn{4}{|c|}{ G2 } & \multicolumn{4}{|c|}{ G3 } \\
\hline & \multirow{2}{*}{7 days } & \multirow{2}{*}{20 days } & \multicolumn{2}{|l|}{7 days } & \multicolumn{2}{|l|}{20 days } & \multicolumn{2}{|l|}{7 days } & \multicolumn{2}{|l|}{20 days } \\
\hline & & & Average & $\mathrm{P}$ & Average & $\mathrm{P}$ & Average & $\mathrm{P}$ & Average & $\mathrm{P}$ \\
\hline Bile & $\begin{array}{c}21421.3333 \\
(\mathrm{SD}-3428.1802)\end{array}$ & $\begin{array}{c}19508.5000 \\
(\mathrm{SD}-4596.4867)\end{array}$ & $\begin{array}{c}19860.0000 \\
(\mathrm{SD}-3825.4420)\end{array}$ & $>0.05$ & $\begin{array}{c}11300.0000 \\
(\mathrm{SD}-3715.1306)\end{array}$ & $>0.05$ & $\begin{array}{c}4440.0000 \\
(\mathrm{SD}-02502.22568)\end{array}$ & $<0.05$ & $\begin{array}{c}4669.5000 \\
(\mathrm{SD}-3575.3098)\end{array}$ & $<0.05$ \\
\hline Glycogen & $\begin{array}{c}46646.5000 \\
(\mathrm{SD}-989.0569)\end{array}$ & $\begin{array}{c}47614.3333 \\
(\mathrm{SD}-2200.4646)\end{array}$ & $\begin{array}{c}32253.1667 \\
(\mathrm{SD}-2957.0761)\end{array}$ & $>0.05$ & $\begin{array}{c}22643.3333 \\
(\mathrm{SD}-4306.6625)\end{array}$ & $<0.05$ & $\begin{array}{c}17687.1667 \\
(\mathrm{SD}-2395.0835)\end{array}$ & $<0.05$ & $\begin{array}{c}10143.8333 \\
(\mathrm{SD}-1861.2162)\end{array}$ & $<0.05$ \\
\hline
\end{tabular}

compared with those of G2 at Day 7 and the control group (Figure 4(a) and Figure 4(c), respectively), and early signs of cytoplasmic vacuolization are observed. In G3 (Figure 3(e) and Figure 3(f)), vacuolization reached its highest level when compared with groups G2 at Days 7 (Figure 4(c)) and 20 (Figure 4(d)) and G3 at Day 7 (Figure 4(e)). Also, fish of G3 at Days 7 and 20 exhibited less glycogen stored $(\mathrm{p}<0.05)$ when compared with individuals of other groups (Table 1).

\section{Discussion}

According to Maduenho, et al. [3], liver damage can be classified into three stages. The 

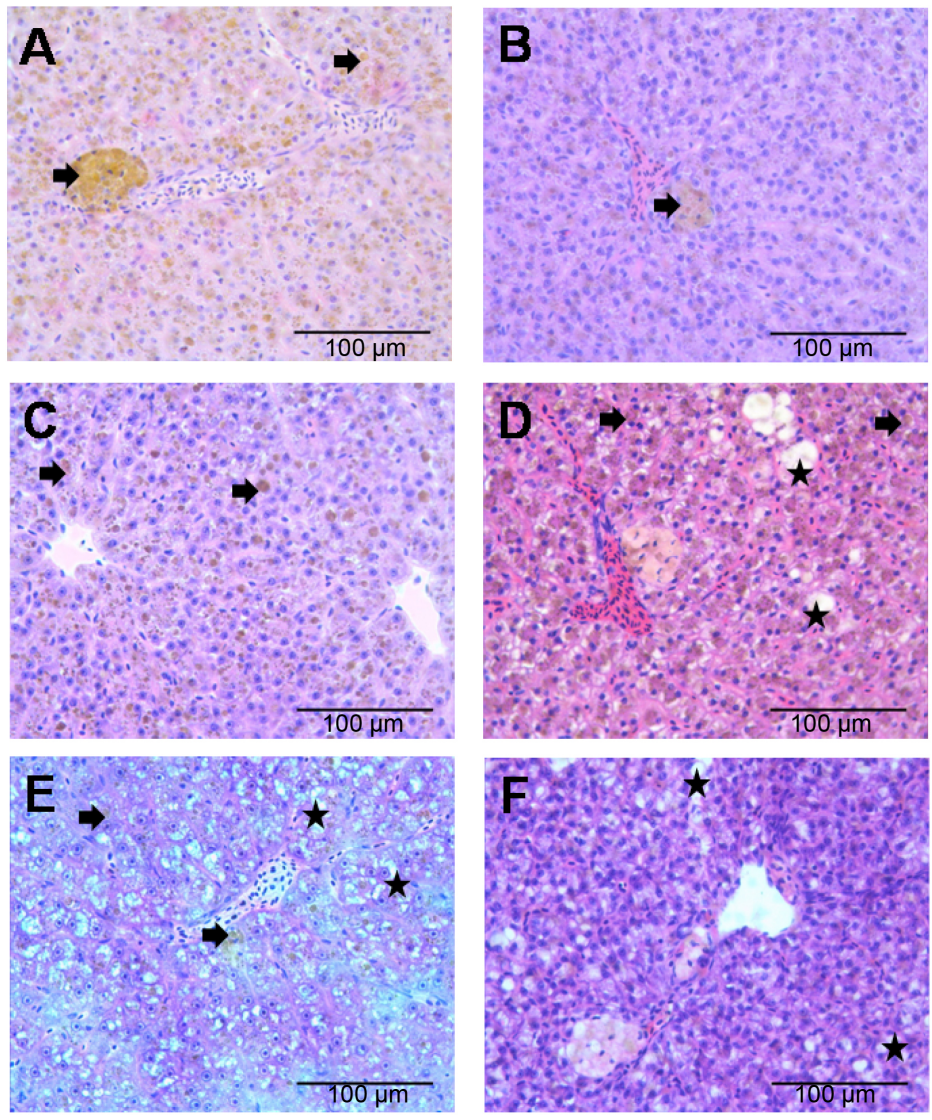

Figure 3. (A) and (B)-Aspect of the liver stained with $\mathrm{H}-\mathrm{E}$ of the control group after 7 and 20 days of experiment respectively. (C) and (D) -Aspect of the liver of the detergent group after 7 and 20 days of experiment respectively. (E) and (F)-Aspect of the liver of the Lago Azul group after 7 and 20 days of experiment respectively. Note that the presence of bile (arrows) decreases in (C), (D), (E) and (F) and that in (D), (E) and (F) it is possible to visualize a vacuolization of the hepatocytes (stars).

first stage is characterized by the presence of clusters of melano macrophages and cellular and nuclear hypertrophy. In the second stage, nuclear vacuolization is observed along with cytoplasmic and nuclear degeneration, bile stagnation, and pyknotic nuclei. In the third stage, alterations impair liver functions, such as processing and storing nutrients absorbed from the digestive tract, neutralization and elimination of toxic substances by biotransformation of chemicals, and bile secretion. Based on these characteristics and the results presented in Table 1, we suggest that in addition to bile stagnation, the area occupied by bile decreases, as observed in G3 at Days 7 and 20.

Another characteristic observed in G2 at Day 20 and G3 at Days 7 and 20 was cytoplasmic vacuolization, which displaced nuclei to the periphery of the cell, as also reported by Pereira, et al. [12]. Of the three stages described by Meyers, et al. [13] and Maduenho, et al. [3], we observed features that characterized the first two stages.

In a similar to xicological study, (Aguiar, et al. [8]) showed that in Anguilla anguilla, fenitrothion reduced levels of glycogen in the liver, in ultrastructural analyses of hepacitos Tilapiatilapia. Oreochromis niloticus exposed to urban pollution, showed drastic 

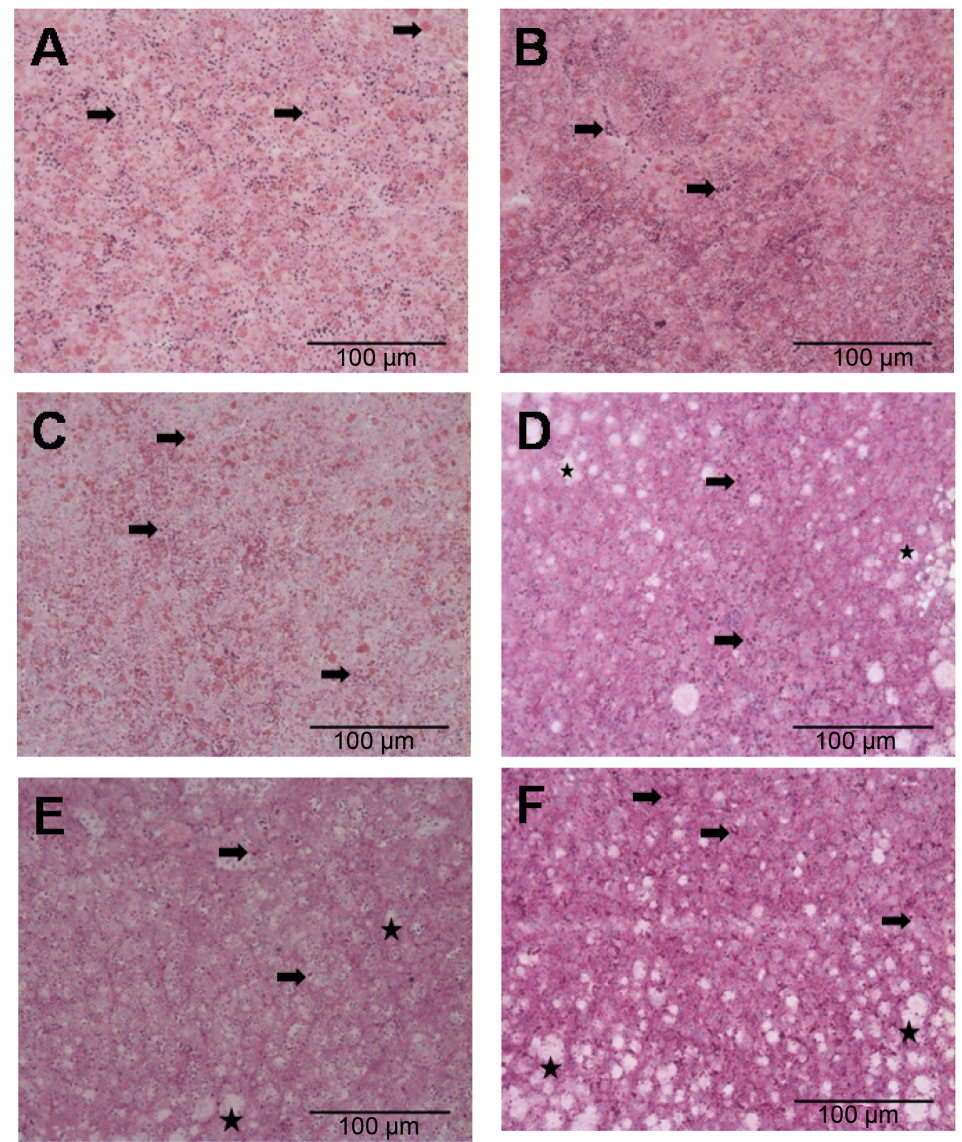

Figure 4. Aspect of the liver stained with PAS of the control group after 7 and 20 days of experiment respectively. (C) and (D) - Aspect of the liver of the detergent group after 7 and 20 days of experiment respectively. (E) and (F)-Aspect of the liver of the Lago Azul group after 7 and 20 days of experiment respectively. Note that the concentration of glycogen (arrows) decreases in the groups' detergent and lagoazul throughout the experiment.

reduction of Glycogent (Vutukuru, et al. [14], Abdel-Moneim [15]), also observed in our study in G2 on the 20th, had a significant decrease in glycogen granules in relation to G2 on Day 7 and the corresponding control group. In G3, the area occupied by glycogen was lower when compared with individuals from other relevant groups.

In G2 and G3, cytoplasmic vacuolization was observed and was more prominent in G3 at Day 20 when compared with G2 at Days 7 and 20 and G3 at Day 7.

In the present study, bile and glycogen levels decreased in the liver of the fish P. lineatus, demonstrating that cells exposed to pollutants lost their capacity to produce this secretion and store nutrients. The damage caused by toxic compounds affects the digestive process and the glycogen reserves of these individuals. This suggests that other tissues might also be damaged, but in a longer term.

Our findings present relevant information, as it involves a disturbed urban area (Lago Azul), and examines the effect of common pollutants in the environment, such as biodegradable detergents. In addition, it also assesses bile and glycogen levels for the first time in ecotoxicological studies of fish. These compounds are important for the 
digestion and storage of nutrients in fish, allowing a better understanding of the effects of pollutants in this species and shedding light to possible bioindicators to be analyzed and quantified.

\section{Acknowledgements}

The authors are thankful to FAPESP for financial support to the projects 2008/51432-0 and 2010/15284-6 and ICMBio/CEPTA-Pirassununga, São Paulo, Brazil for providing the fish used in this study.

\section{References}

[1] Silva, R.G. (2006) da Análise da estrutura genética populacional do curimbatá (Prochilodus lineatus, Characiformes: Prochilodontidae) na região da bacia do Rio Grande, 2016. SP. 112f.Dissertação (Mestrado em Genética)—Universidade do Estado de São Paulo, São Paulo.

[2] Barbieri, G., Salles, F.A. and Cestarolli, M.A. (2000) Análise populacional do curimbatá, Prochilodus lineatus, do rio Mogi Guaçu, Pirassununga/SP (Characiformes, Prochilodontidae). B. Inst. Pesca, 26, 137-145.

[3] Maduenho, L.P. and Martinez, C.B.R. (2008) Acute Effects of Diflubenzuron on the Freshwater Fish Prochilodus lineatus. Comparative Biochemistry and Physiology Part C: Toxicology \& Pharmacology, 148, 265-272.

[4] Mumford, S., Heidel, J., Smith, C., Morrison, J., Macconnell, B. and Blazer, V. (2010) Fish Histology and Histopathology. Shepherdstown, West Virginia-United States of America, National Conservation Training Center. 357 p.

[5] Gerber, M.A. and Thung, S.N. (1987) Histology of the Liver. American Journal of Surgical Pathology, 11, 709-722. https://doi.org/10.1097/00000478-198709000-00007

[6] Simonato, J.D., Guedes, C.L.B. and Martinez, C.B.R. (2008) Biochemical, Physiological, and Histological Changes in the Neotropical Fish Prochilodus lineatus Exposed to Diesel Oil. Ecotoxicology and Enviromental Safety, 69, 112-120. https://doi.org/10.1016/j.ecoenv.2007.01.012

[7] Jiraungkoorskul, W., Upatham, E.S., Kruatrachue, M., Sahaphong, S., Vichasri-Gramas, S. and Pokethitiyook, P. (2002) Histopathological Effects of Roundup, a Glyphosate Herbicide, on Nile Tilapia (Oreochromis niloticus). Science Asia, 28, 121-127. https://doi.org/10.2306/scienceasia1513-1874.2002.28.121

[8] De Aguiar, L.H., Moraes, G., Avilez, I.M., Altran, A.E. and Corrêa, C.F. (2004) Metabolical Effects of Folidol 600 on the Neotropical Freshwater Fish Matrinxã, Brycon cephalus. Environmental Research, 95, 224-230. https://doi.org/10.1016/S0013-9351(03)00119-1

[9] Bols, N.C., Brubacher, J.L., Ganassin, R.C. and Lee, L.E.J. (2001) Ecotoxicology and Innate Immunity in Fish. Developmental \& Comparative Immunology, 25, 853-873. https://doi.org/10.1016/S0145-305X(01)00040-4

[10] Bols, N.C., Dayeh, V.R., Lee, L.E.J. and Schirmer, K. (2005) Use of Fish Cell Lines in the Toxicology and Ecotoxicology of Fish. Piscine Cell Lines in Environmental Toxicology. Biochemistry and Molecular Biology of Fishes, 6, 43-84. https://doi.org/10.1016/S1873-0140(05)80005-0

[11] Campos, C.M.D., Moraes, J.R.E. and Moraes, F.R.D. (2008) Histopathology of Liver, Kidney and Spleen of Piaractus mesopotamicus, Prochilodus lineatus and Pseudoplatystoma fasciatum Infected by Myxosporean Parasite, Caugth in Aquidauana River, Mato Grosso do Sul, Brazil. Revista Brasileira de Parasitologia Veterinária, 17, 200-205.

[12] Pereira, B.F., da Silva Alves, R.M., Alves, A.L., Senhorin, J.A., de Alcântara Rocha, R.C.G., 
Scalize, P.H., Pitol, D.L. and Caetano, F.H. (2014) Effects of Biodegradable Detergents in Morphological Parameters of Liver in Two Neotropical Fish Species (Prochilodus lineatus and Astyanax altiparanae). Microscopy Research, 2, 39-49.

https://doi.org/10.4236/mr.2014.22006

[13] Meyers, T.R. and Hendricks, J.D. (1982) A Summary of Tissue Lesions in Aquatic Animals Induced by Controlled Exposures to Environmental Contaminants, Chemotherapeutic Agents, and Potential Carcinogens. Marine Fisheries Review, 44, 1-17.

[14] Vutukuru, S.S. and Basani, K. (2013) Acute Effects of Mercuric Chloride on Glycogen and Protein Content of Zebra Fish, Daniorerio. Journal of Environmental Biology, 34, 277-281.

[15] Abdel-Moneim, A.M. (2014) Histopathological and Ultrastructural Perturbations in Tilapia Liver as Potential Indicators of Pollution in Lake Al-Asfar, Saudi Arabia. Environmental Science and Pollution Research, 21, 4387-4396. https://doi.org/10.1007/s11356-013-2185-9

Submit or recommend next manuscript to SCIRP and we will provide best service for you:

Accepting pre-submission inquiries through Email, Facebook, LinkedIn, Twitter, etc. A wide selection of journals (inclusive of 9 subjects, more than 200 journals) Providing 24-hour high-quality service User-friendly online submission system Fair and swift peer-review system Efficient typesetting and proofreading procedure Display of the result of downloads and visits, as well as the number of cited articles Maximum dissemination of your research work

Submit your manuscript at: http://papersubmission.scirp.org/ Or contact mr@scirp.org 